\title{
PENGARUH HARGA, KUALITAS PRODUK, DAN PROMOSI TERHADAP KEPUTUSAN PEMBELIAN MARKETPLACE SHOPEE
}

\author{
Rizky Dwijantoro, Bernadin Dwi, dan Nobelson Syarief \\ Universitas Pembangunan Nasional Veteran Jakarta \\ Email korespondensi: rizky.dwijantoro@upnvj.ac.id \\ http://dx.doi.org/10.21460/jrmb.2021.162.392
}

\begin{abstract}
ABSTRAK
Penelitian ini menggunakan metode deskriptif kuantitatif yang dilakukan pada pelanggan marketplace Shopee. Tujuan dari penelitian ini adalah untuk mengetahui dan membuktikan apakah keputusan pembelian pada marketplace Shopee dipengaruhi oleh harga, kualitas produk dan promosi. Populasi dalam penelitian ini adalah mahasiswa yang pernah melakukan pembelian melalui Shopee. Sampel yang diambil dalam penelitian ini yaitu berjumlah 75 responden dengan metode Purposive Sampling dengan menyebarkan kuisioner melalui googleform. Teknik analisis yang digunakan adalah analisis deskriptif dan analisis inferensial dengan menggunakan alat analisis Partial Least Square (PLS). Hasil penelitian menunjukan bahwa variabel harga dan kualitas produk berpengaruh terhadap keputusan pembelian. Promosi juga yang berpengaruh positif dan signifikan terhadap keputusan pembelian.
\end{abstract}

Kata Kunci: keputusan pembelian, harga, kualitas produk, promosi

\begin{abstract}
This study uses a quantitative descriptive method conducted on Shopee marketplace customers. The purpose of this research is to find out and prove whether purchasing decisions in the Shopee marketplace are determined by price, product quality, and promotion. The population in this study were students who had made purchases through Shopee. The sample taken in this study was to find 75 respondents using the purposive sampling method by distributing questionnaires through google form. The analytical technique used is descriptive analysis and inferential analysis using Partial Least Square (PLS) analysis tool. The results showed that the variables of price and product quality had an effect on purchasing decisions. Promotion also has a positive and significant effect on purchasing decisions.
\end{abstract}

Keywords: purchase decision, price, product quality, promotion

\section{PENDAHULUAN}

Pada era modernisasi saat ini, teknologi dan informasi mengalami perkembangan yang sangat pesat terutama internet. Adanya Kecenderungan memakai gadget salah satunya menjadi perubahan gaya hidup masyarakat yang sekarang mereka melakukan aktivitasnya di dunia maya misalkan berbelanja secara online (Fahrevi \& Satrio, 2018).
Pertumbuhan e-commerce berkembang cukup pesat walaupun pada masa pandemi sekarang ini. Sebagai buktinya yaitu kenaikan pembelian dari melalui e-commerce hingga pencapaian sebanyak $18,1 \%$ atau 98,3 juta transaksi dari total transaksi sejumlah $\$ 1,4$ juta USD (Maulana, 2021).

Berdasarkan data dari BI (Bank Indonesia), tercatat sebanyak hampir dua kali lipat dari jumlah transaksi jual beli di $e$ - 
commerce mengalami peningkatan di pertengahan COVID-19 ini. Dengan jumlah lonjakan yang berawal 80 juta transaksi di tahun 2019 meningkat jadi 140 juta transaksi hingga bulan Agustus 2020 (Uli, 2020).

Snapchart, aplikasi online yang digunakan dalam melakukan riset pasar, mengetahui segala macam tren belanja online yang timbul sepanjang bulan Ramadhan serta Hari Raya Lebaran 2020 yang beroperasi pada pertengahan pendemi COVID-19. Riset tersebut memperlihatkan terdapat $66 \%$ penduduk dari 1.000 responden yang menjatuhkan pilihannya kepada Shopee selaku situs belanja online yang dipergunakan dan senantiasa diingat sepanjang bulan Ramadhan dan Hari Raya Lebaran 2020. Secara detailnya, berdasar pada riset tersebut, terdapat $58 \%$ pembeli pada Jabodetabek yang menjatuhkan pilihannya kepada Shopee selaku situs belanja online yang tidak bisa dilupakan serta $72 \%$ pembeli dengan asal luar Jabodetabek.

Lebih lanjut, terdapat sejumlah $77 \%$ perempuan yang berbelanja menggunakan Shopee sementara pria sejumlah $52 \%$. Sebaliknya di Tokopedia, banyak laki-laki yang menggunakan platform ini dari persentase $22 \%$ dibanding perempuan hanya $9 \%$. Menurut usia, pengguna Shopee kebanyakan golongan anak muda yang menyukai platform itu dengan kisaran usia 19-24 tahun, Lazada dengan usia dibawah usia 19 tahun yang menyukai palatform itu, dengan Bukalapak dan Tokopedia kebanyakan golongan usia lebih dari 35 tahun yang menyukai platform itu (Catriana, 2020).

Adapun survei yang digelar APJII (Asosiasi Penyelenggara Jasa Internet Indonesia) dari sampel sejumlah 7.000 responden dengan level of confidence $95 \%$ dan margin of error $1,27 \%$. Sampel paling besar di keseluruhan provinsi di Indonesia mengenai pemakaian internet di tahun 2019 sampai kuartal II 2020. Marketplace yang sangat sering dikunjungi yaitu Shopee pada pencapaian 27,4 $\%$ kemudian Lazada pada capaian 14,2\%, serta Tokopedia 5,2\%. Pembelian keperluan secara online karena beberapa alasan yaitu yang pertama alasan terbesarnya yakni harga yang diberikan sangat terjangkau atau murah pada capaian 15,2\% (Pebrianto, 2020).

Tidak hanya itu, Shopee juga menggelar kampanye promosi dilakukan tiap bulan semenjak bulan Februari tahun 2020. Nama programnya pun diselaraskan dengan barang dan waktu yang dilakukan promosi, sebagai contoh 2.2 Men Sale, 3.3 Fashion Sale sampai yang paling baru 10.10 Brands Festival.

Melalui begitu banyak promosi, platform shopee menghasilkan jumlah pesanan bruto mengalami pertumbuhan secara tahunan (year on year/yoy) dari capaian $150,1 \%$ berubah jadi 615,9 juta di kuartal II (Setyowati, 2020).

Mengacu pada data yang dirilis iPrice, terdapat 3 e-commerce di tahun 2019 dengan pengunjung paling besar yaitu Bukalapak, Tokopedia, serta Shopee. Jika berdasarkan dari peringkat Playstore dan Appstore, Shoppe menduduki rangking pertama dibanding Tokopedia padahal Tokopedia merupakan platform yang telah lama ada sebelum platform Shoope ada (Rachel, 2019).

Dari pemaparan beberapa data di atas, Shopee yang menempati posisi puncak sebagai marketplace terpopuler yang tentunya ada sejumlah faktor yang memotivasi dan mempengaruhi keputusan pembelian oleh pembeli.

Berdasar pada fenomena yang sedang terjadi itu, peneliti kemudian tertarik untuk menguji dan mengkaji lebih dalam lagi mengenai latar belakang di atas yang dimana peneliti ingin menganalisis latar belakang tersebut dengan demografi yang berbeda dan keadaan yang beda dengan penelitian sebelumnya dimana peneliti melakukan penelitian pada saat situasi pandemi covid-19 yang beda dengan penelitian terdahulu.

Adapun perumusan masalah dalam penelitian ini adalah: Apakah harga, kualitas produk, dan promosi mempunyai pengaruh terhadap keputusan pembelian pada marketplace Shopee? Tujuan penelitian adalah untuk mengetahui, membuktikan, dan menganalisis apakah apakah harga, kualitas produk, dan promosi mempunyai pengaruh terhadap keputusan pembelian pada marketplace Shopee.

\section{KAJIAN LITERATUR}

\section{Keputusan Pembelian}

Menurut Kotler \& Keller (2016, hlm.177), keputusan pembelian yakni ialah elemen dari perilaku pelanggan yakni riset 
mengenai bagaimana organisasi, individu, ataupun kelompok yang menjatuhkan pilihan, memutuskan pembelian, memakai, dan bagaimana pengalaman, ide, barang atau jasa itu dipergunakan sebagai pemberian kepuasan keinginan dan kebutuhan mereka. Sesuai pandangan Kotler \& Armstrong (2018, hlm.175), keputusan pembelian konsumen yaitu pembelian merek dimana mereka sangat menyukainya, namun 2 faktor bisa terjadi diantara keputusan pembelian dengan niat membeli.

Kesimpulannya adalah bahwa purchase decisions (keputusan pembelian) yaitu proses dalam mengambil keputusan untuk membeli, dimana calon konsumen menjatuhkan pilihan, memutuskan pembelian, dan memberikan kepuasan akan keinginan dan kebutuhan mereka.

\section{Harga}

Menurut Kotler \& Armstrong (2018, hlm.308), harga ialah pengeluaran sejumlah uang pelanggan guna mendapat pemakaian atau manfaat atau kepemilikan dari suatu barang atau pelayanan. Kotler \& Keller (2016, hlm.483) juga menyatakan bahwa harga adalah suatu bagian dari bauran pemasaran yang memperoleh hasil pendapatan; sebaliknya bagian lain yang memperoleh hasil biaya. Harga pula menyampaikan posisi nilai yang diharapkan atas merek atau produk perusahaan. Barang yang telah didesain kemudian dijual secara hati-hati masih bisa dihargai dan menguntungkan.

Jadi dapat ditarik kesimpulan, harga yaitu sejumlah uang yang dikeluarkan untuk konsumen mendapatkan pemakaian, manfaat atau kepemilikan dari suatu barang atau pelayanan.

Harga sendiri berdasarkan penelitian terdahulu yang dilakukan oleh Prilano \& Sudarso (2020); Tulangow, Tumbel, \& Walangitan (2019); Ilmiyah \& Indra (2020); Kuswanto \& Vikaliana (2020); Silaban \& Rosdiana (2020); Aryani (2016); Wulandari, Mulyati, \& Tjahjono (2020); Albari \& Safitri (2018); Akbar (2020); dan Mulya Firdausy \& Idawati (2017) dinyatakan berpengaruh terhadap keputusan pembelian.

\section{Kualitas Produk}

Menurut Amstrong et al. (2018, hlm.205), kualitas produk yaitu suatu alat pemosisian utama untuk pemasar. Secara langsung, kualitas memberi pengaruh pada kinerja sebuah barang atau pelayanan, sehingga berkaitan erat dengan kepuasan dan nilai konsumen. Definisi kualitas produk sesuai pemaparan Kotler \& Keller (2016, hlm.156) yaitu seluruh karakteristik kemampuan akan sebuah barang atau pelayanan sebagai pemenuhan keperluan pemakai dengan implikasi dan ekspresinya merupakan pemberian atas kepuasan konsumen.

Dengan demikian, kualitas produk yaitu karakteristik secara menyeluruh kemampuan atas sebuah barang atau layanan guna memuaskan atau sebagai pemenuhan keperluan pelanggannya. Kualitas produk berdasarkan penelitian terdahulu yang telah dilakukan oleh Akbar (2020) dimana dari hasil riset tersebut menunjukan bahwa variabel kualitas produk memiliki pengaruh terhadap keputusan pembelian.

\section{Promosi}

Menurut Chaffey and Smith (2017), promosi merupakan opsi daring untuk semua elemen bauran promosi - mulai dari iklan, penjualan, promosi penjualan, PR, sponsor, surat langsung, pameran, merchandizing, pengemasan, dari mulut ke mulut. Menurut Kotler \& Keller (2016, hlm.622), promosi penjualan ialah kunci utamanya ketika berkampanye pemasaran, yang terbagi atas sekumpulan alat insentif, dengan hampir keseluruhan mempunyai sifat berjangka pendek yang dilakukan perancangan untuk memberikan daya rangsang pembelian atas suatu barang atau jasa tertentu secara lebih cepat untuk pelanggan.

Kesimpulannya adalah cara penjual mempresentasikan produknya pada konsumen, dengan tujuan untuk menyampaikan informasi mengenai produk agar mereka mau membeli produk yang ditawarkan. Promosi berdasarkan penelitian terdahulu yang telah dilakukan oleh Tulangow, Tumbel, \& Walangitan (2019); Prilano \& Sudarso (2020); Mulya Firdausy \& Idawati (2017) dinyatakan berpengaruh terhadap keputusan pembelian.

\section{Model Penelitian Empiris}


Berdasarkan penjelasan di atas, variabel independen pada riset ini yakni variabel promosi, harga, serta kualitas produk terhadap variabel tergantung yakni variabel keputusan pembelian. Gambaran tersebut terlihat pada gambar berikut:

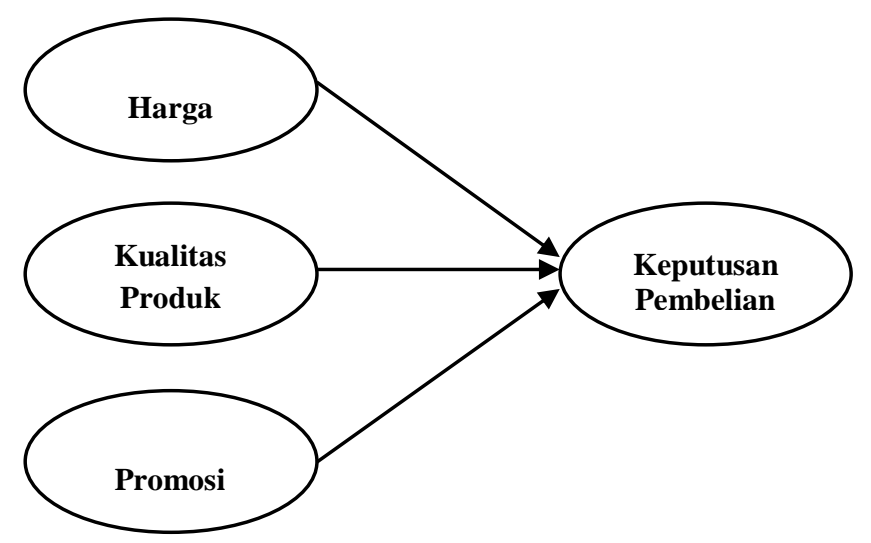

Gambar 1. Model Penelitian

\section{Hipotesis}

Berdasar pada pemaparan latar belakang, rumusan permasalahan, tinjauan pustaka serta sejumlah penelitian sebelumnya bisa menjadi bahan rujukan pada penelitian ini. Maka penulis merumuskan hipotesis atau dugaan sementara atas permasalahan yang akan diteliti yaitu:

H1: Diduga harga memberi pengaruh terhadap keputusan pembelian.

H2: Diduga kualitas produk memberi pengaruh terhadap keputusan pembelian.

H3: Diduga promosi memberi pengaruh terhadap keputusan pembelian.

\section{METODA PENELITIAN}

\section{Populasi dan Sampel}

Populasi pada riset ini yakni mahasiswa pengguna aplikasi Shopee yang berlokasi di Wilayah Jakarta Selatan. Sementara untuk sampel, dalam penelitian ini menggunakan teknik pengambilan sampel purposive sampling. Dimana acuan dalam menentukan ukuran sampel didasari pernyataan dari Roscoe dalam Ferdinand (2014, hlm. 173) yang mengatakan bahwa "ukuran sampel yang dianggap layak adalah lebih besar dari 30 dan kurang dari 500". Adapun didalam penelitian ini banyaknya jumlah sampel itu sendiri ditentukan dari 25 dikali dengan jumlah variabel independen. Maka jumlah sampel dalam penelitian ini ditentukan sebesar 25 dikali dengan 3 variabel independen, dimana hasilnya yakni sebanyak 75 sampel.

\section{Teknik Pengumpulan Data}

Jenis data yang dipergunakan yakni data kuantitatif. Dan sumber data menggunakan data primer yang didapat melalaui google form.

\section{Teknik Analisis dan Uji Hipotesis}

Teknik analisis data yang dipergunakan oleh peneliti yaitu teknik analisis deskriptif, yang mana dipergunakan sebagai pemberian deskripsi secara empiris dari data yang telah terhimpun (Ferdinand, 2014 hlm.229).

Dalam penelitian ini analisis deskriptif ini menggunakan hasil perhitungan dari output SmartPLS 3.3.2 yaitu berdasarkan nilai mean, minimum, maximum dan standar deviasi. Nilai minimum digunakan untuk untuk melihat nilai paling terkecil pada masing-masing variabel, sedangkan nilai maksimum digunakan untuk melihat nilai terbesar pada masing-masing variabel. Nilai mean adalah nilai rata-rata atas sekumpulan data variabel-variabel dalam penelitian. Standar deviasi dalam penelitian ini digunakan untuk melihat tinggi rendahnya menyimpangan atau variasi suatu data. Variabel dalam penelitian ini adalah harga, kualitas produk dan promosi, sedangkan variabel dependen dalam penelitian ini adalah keputusan pembelian. 
Sementara analisis inferensial dalam penelitian ini dilakukan melalui Partial Least Square guna menganalisis data responden, sementara hasil pengolahan data yang diperoleh akan diambil kesimpulan dari sampel tersebut. Adapun dalam penelitian ini akan dilakukan uji validitas, uli reliabilitas, uji koefisien determinasi, dan uji hipotesis menggunakan uji t statistik.

\section{HASIL DAN PEMBAHASAN}

\section{Deskripsi Data Responden}

Jumlah responden yang berjenis kelamin laki-laki sebanyak 38 orang dan jumlah responden yang berjenis kelamin perempuan sebanyak 37 orang. Jumlah responden yang melakukan pembelian sebanyak 3-5 kali berjumlah 21 mahasiswa, jumlah responden yang melakukan pembelian sebanyak 6-8 kali berjumlah 14 mahasiswa kemudian jumlah responden yang melakukan pembelian sebanyak 9-10 kali sebanyak 16 orang dan jumlah responden yang melakukan pembelian lebih dari 10 kali yaitu sebanyak 24 mahasiswa. Jumlah mahasiswa yang berusia antara 17 sampai 20 tahun sebanyak 38 orang, Sementara itu responden yang berusia 21 sampai 25 tahun berjumlah sebanyak 37 orang.

\section{Analisis Deskriptif}

\section{Persepsi Responden tentang Keputusan Pembelian}

Berdasarkan Tabel 1 yang telah diperoleh dari hasil output PLS, dapat terlihat nilai rata-rata (mean) paling besar terdapat pada butir pertanyaan KB 12 dengan nilai sebesar 4.373, angka tersebut dapat diartikan bahwa responden setuju terhadap pernyataan "pembayaran pada Shopee dapat dilakukan melalui transfer bank" karena pembayarannya dapat dilakukan melalui transfer bank. Nilai rata-rata (mean) terkecil pada butir pertanyaan KB 7 dengan nilai sebesar 3.240, angka tersebut artinya responden ragu-ragu tentang tidak adanya batasan jumlah pesanan dalam marketplace Shopee. Selanjutnya dapat dilihat bahwa nilai minimum dalam setiap butir pertanyaan variabel keputusan pembelian, responden memberikan nilai dengan skor 1 dan nilai maksimum yang dinilai responden dari setiap butir pertanyaan pada variabel keputusan pembelian adalah skor 4 dan 5 . Nilai standar deviasi pada setiap butir pertanyaan variabel keputusan pembelian memiliki nilai lebih kecil dari nilai rata-rata (mean) dimana menunjukan bahwa tidak adanya penyimpangan data yang cukup besar pada variabel keputusan pembelian.

\section{Persepsi Responden tentang Harga}

Berdasarkan hasil tabel yang telah diperoleh dari hasil output PLS. dapat terlihat nilai rata-rata (mean) paling besar terdapat pada butir pertanyaan $\mathrm{H} 5$ dengan nilai sebesar 4.693, angka tersebut dapat diartikan bahwa responden setuju bahwa harga produk yang ditawarkan Shopee selaras dengan manfaat yang diberikan, dan nilai rata-rata (mean) terkecil pada butir pertanyaan $\mathrm{H} 1$ dengan nilai sebesar 4.493, angka tersebut artinya bahwa responden menyukai berbelanja melalui Shopee karena harga produk yang ditawarkan relatif terjangkau. Selanjutnya dapat dilihat bahwa nilai minimum dalam setiap butir pertanyaan variabel keputusan pembelian, responden memberikan nilai dengan skor 1 dan 2. Dan nilai maksimum yang dinilai responden dari setiap butir pertanyaan pada variabel keputusan pembelian adalah skor 5. Nilai standar deviasi pada setiap butir pertanyaan variabel keputusan pembelian memiliki nilai lebih kecil dari nilai rata-rata (mean) dimana menunjukan bahwa tidak adanya penyimpangan data yang cukup besar pada variabel harga.

\section{Persepsi Responden tentang Kualitas Produk}

Berdasarkan Tabel 2 yang telah diperoleh dari hasil output PLS. dapat terlihat nilai rata-rata (mean) paling besar terdapat pada butir pertanyaan KP 4 dengan nilai sebesar 4.587, angka tersebut dapat diartikan bahwa responden setuju bahwa kualitas produk yang ditawarkan Shopee tidak mengecewakan. dan nilai rata-rata (mean) terkecil pada butir pertanyaan KP 3 dengan nilai sebesar 4.280, angka tersebut artinya bahwa responden setuju bahwa produk yang diberikan Shopee selaras dengan deskripsi yang dibagikan. 
Tabel 1. Statistik Deskriptif Variabel Keputusan Pembelian

\begin{tabular}{ccccc}
\hline Butir Pertanyaan & Mean & Minimum & Maximum & Standar Deviasi \\
\hline KB1 & 3.333 & 1.000 & 4.000 & 0.718 \\
KB2 & 3.693 & 1.000 & 4.000 & 0.632 \\
KB3 & 3.613 & 1.000 & 4.000 & 0.728 \\
KB4 & 3.520 & 1.000 & 4.000 & 0.755 \\
KB5 & 3.320 & 1.000 & 4.000 & 0.751 \\
KB6 & 3.280 & 1.000 & 4.000 & 0.704 \\
KB7 & 3.240 & 1.000 & 4.000 & 0.797 \\
KB8 & 3.587 & 1.000 & 4.000 & 0.655 \\
KB9 & 3.333 & 1.000 & 4.000 & 0.699 \\
KB10 & 3.387 & 1.000 & 4.000 & 0.691 \\
KB11 & 4.093 & 1.000 & 5.000 & 0.941 \\
KB12 & 4.373 & 1.000 & 5.000 & 0.845 \\
\hline
\end{tabular}

Selanjutnya dapat dilihat bahwa nilai minimum dalam setiap butir pertanyaan variabel keputusan pembelian, responden memberikan nilai dengan skor 1 dan 2. Dan nilai maksimum yang dinilai responden dari setiap butir pertanyaan pada variabel keputusan pembelian adalah skor 5 untung butir pertanyaan KP 1 sampai KP 10. Nilai standar deviasi pada setiap butir pertanyaan variabel keputusan pembelian memiliki nilai lebih kecil dari nilai rata-rata (mean) dimana menunjukan bahwa tidak adanya penyimpangan data yang cukup besar pada variabel kualitas produk.

Tabel 2. Statistik Deskriptif Variabel Harga

\begin{tabular}{ccccc}
\hline Butir Pertanyaan & Mean & Minimum & Maximum & Standar Deviasi \\
\hline H1 & 4.493 & 2.000 & 5.000 & 0.941 \\
H2 & 4.547 & 1.000 & 5.000 & 0.845 \\
H3 & 4.520 & 1.000 & 5.000 & 0.755 \\
H4 & 4.627 & 2.000 & 5.000 & 0.688 \\
H5 & 4.693 & 1.000 & 5.000 & 0.610 \\
H6 & 4.653 & 2.000 & 5.000 & 0.600 \\
\hline
\end{tabular}

Tabel 3. Statistik Deskriptif Variabel Kualitas Produk

\begin{tabular}{|c|c|c|c|c|}
\hline Butir Pertanyaan & Mean & Minimum & Maximum & Standar Deviasi \\
\hline KP1 & 4.507 & 2.000 & 5.000 & 0.719 \\
\hline KP2 & 4.573 & 1.000 & 5.000 & 0.769 \\
\hline KP3 & 4.280 & 2.000 & 5.000 & 0.974 \\
\hline KP4 & 4.587 & 1.000 & 5.000 & 0.768 \\
\hline KP5 & 4.467 & 1.000 & 5.000 & 0.884 \\
\hline KP6 & 4.280 & 1.000 & 5.000 & 0.873 \\
\hline KP7 & 4.387 & 1.000 & 5.000 & 0.831 \\
\hline KP8 & 4.347 & 1.000 & 5.000 & 0.808 \\
\hline KP9 & 4.507 & 2.000 & 5.000 & 0.755 \\
\hline KP10 & 4.480 & 1.000 & 5.000 & 0.822 \\
\hline \multicolumn{5}{|c|}{ Tabel 4. Statistik Deskriptif Variabel Promosi } \\
\hline Butir Pertanyaan & Mean & Minimum & Maximum & Standar Deviasi \\
\hline P1 & 3.653 & 1.000 & 4.000 & 0.662 \\
\hline $\mathrm{P} 2$ & 3.520 & 1.000 & 4.000 & 0.661 \\
\hline P3 & 3.493 & 1.000 & 4.000 & 0.681 \\
\hline P4 & 2.973 & 1.000 & 4.000 & 0.938 \\
\hline P5 & 3.653 & 1.000 & 4.000 & 0.663 \\
\hline P6 & 3.187 & 1.000 & 4.000 & 0.761 \\
\hline P7 & 3.533 & 1.000 & 4.000 & 0.639 \\
\hline
\end{tabular}




\begin{tabular}{ccccc}
\hline Butir Pertanyaan & Mean & Minimum & Maximum & Standar Deviasi \\
\hline P8 & 3.613 & 1.000 & 4.000 & 0.651 \\
P9 & 3.747 & 1.000 & 4.000 & 0.591 \\
P10 & 3.253 & 1.000 & 4.000 & 0.750 \\
\hline
\end{tabular}

\section{Persepsi Responden tentang Promosi}

Berdasarkan Tabel 4 yang telah diperoleh dari hasil output PLS, terlihat nilai rata-rata (mean) paling besar terdapat pada butir pertanyaan P 9 dengan nilai sebesar 3.747. Angka tersebut dapat diartikan bahwa responden ragu-ragu tentang pernyataan bahwa Shopee sering melakukan promosi dengan media massa dan nilai rata-rata (mean) terkecil pada butir pertanyaan $\mathrm{P} 4$ dengan nilai sebesar 2.973. Angka tersebut artinya bahwa konsumen tidak setuju bahwa dengan adanya pemberian gratis ongkos kirim pada jumlah pemesanan tertentu dapat menarik perhatian untuk melakukan pembelian. Selanjutnya, dapat dilihat bahwa nilai minimum dalam setiap butir pertanyaan variabel keputusan pembelian, responden memberikan nilai dengan skor 1 dan nilai maksimum yang dinilai responden dari setiap butir pertanyaan pada variabel keputusan pembelian adalah skor 4 untung butir pertanyaan $\mathrm{P} 1$ sampai $\mathrm{P} 10$. Nilai standar deviasi pada setiap butir pertanyaan variabel keputusan pembelian memiliki nilai lebih kecil dari nilai rata-rata (mean) dimana menunjukan bahwa tidak adanya penyimpangan data yang cukup besar pada variabel promosi.

\section{Analisis Inferensial}

Analisis inferensial merupakan sebuah teknik analisis yang pada umumnya digunakan pada bidang manajemen sebagai penentu sebarapa jauh persamaan dari hasil yang didapapatkan dengan hasil keseluruhan populasi. Alat untuk menganalisis data dalam penelitian ini adalah menggunakan Partial Least Square (PLS).

\section{Model Pengukuran (Outer Model)}

Outer model memiliki tiap blok indikator yang berhubungan dengan variabel latennya. Merancang pengukuran model dalam menentukan sifat indikator juga tiap variabel laten, apakah refleksif atau formatif hasilnya. Dasarnya adalah berdasarkan teori, penelitian empiris terdahulu, atau rasional. Hasil uji validitas diagram jalur SmartPLS 3.3.2 digambarkan sebagai berikut:

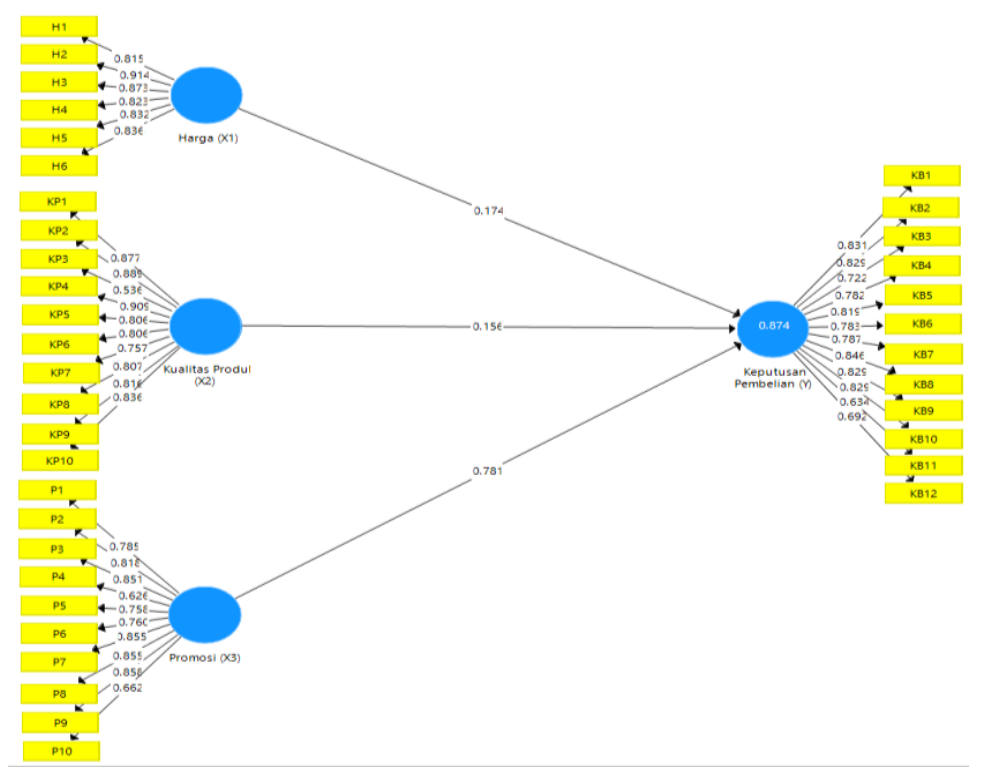

Gambar 2. Outer Model

Berdasarkan gambar hasil output d iatas, terlihat bahwa variabel reflektif pada penelitian ini yaitu variabel harga, kualitas produk dan promosi memiliki nilai loading factor $>0.7$ 
dimana ini menunjukan bahwa telah memenuhi syarat untuk valid dan tidak memiliki masalah karena skala loading 0.5 - 0.6 masih dapat diterima dalam tahap pengembangan (Ghozali, 2014, hlm. 39). Pada gambar di atas menunjukan bahwa nilai loading factor terendah dari masing-masing indikator variabel yaitu pada H1, KP3, P4, dan KB11 dimana nilai tersebut masih dapat diterima karena diatas skala loading 0.5 sejalan dengan penjelasan Ghozali di atas dan dapat disimpulkan bahwa semua instrumen pertanyaan dalam penelitian ini memiliki nilai loading factor di atas 0.5 dan penelitian dapat dilanjutkan.

\section{Uji Validitas}

Sesuai pandangan Ghozali (2014, hlm.39), uji validitas dipakai guna pengukuran salah satu valid ataupun tidak sebuah angket. Sebuah angket dinyatakan valid bila pertanyaan di angket sanggup dalam mengutarakan suatu hal yang akan dilakukan pengukuran oleh angket tersebut.

Tabel 5. Convergent Validity melalui Output Loading Factor

\begin{tabular}{|c|c|c|c|c|}
\hline & Keputusan Pembelian & Harga & Kualitas Produk & Promosi \\
\hline KB1 & 0.831 & & & \\
\hline KB2 & 0.829 & & & \\
\hline KB3 & 0.722 & & & \\
\hline KB4 & 0.782 & & & \\
\hline KB5 & 0.819 & & & \\
\hline KB6 & 0.783 & & & \\
\hline KB7 & 0.787 & & & \\
\hline KB8 & 0.846 & & & \\
\hline KB9 & 0.829 & & & \\
\hline KB10 & 0.831 & & & \\
\hline KB11 & 0.634 & & & \\
\hline KB12 & 0.692 & & & \\
\hline $\mathrm{H} 1$ & & 0.815 & & \\
\hline $\mathrm{H} 2$ & & 0.914 & & \\
\hline $\mathrm{H} 3$ & & 0.873 & & \\
\hline $\mathrm{H} 4$ & & 0.823 & & \\
\hline H5 & & 0.832 & & \\
\hline H6 & & 0.836 & & \\
\hline KP1 & & & 0.877 & \\
\hline KP2 & & & 0.889 & \\
\hline KP3 & & & 0.536 & \\
\hline KP4 & & & 0.909 & \\
\hline KP5 & & & 0.806 & \\
\hline KP6 & & & 0.806 & \\
\hline KP7 & & & 0.757 & \\
\hline KP8 & & & 0.807 & \\
\hline KP9 & & & 0.816 & \\
\hline KP10 & & & 0.836 & \\
\hline P1 & & & & 0.785 \\
\hline P2 & & & & 0.818 \\
\hline P3 & & & & 0.851 \\
\hline P4 & & & & 0.626 \\
\hline P5 & & & & 0.758 \\
\hline P6 & & & & 0.760 \\
\hline P7 & & & & 0.855 \\
\hline P8 & & & & 0.855 \\
\hline P9 & & & & 0.858 \\
\hline P10 & & & & 0.662 \\
\hline
\end{tabular}


Berdasarkan tabel di atas, menunjukkan bahwa nilai loading factor berada di atas 0.50 pada tabel di atas nilai tertinggi yaitu pada kontruk $\mathrm{H} 2$ yaitu sebesar 0.914 , lalu untuk nilai terendah pada tabel tersebut adalah pada butir pertanyaan KP3 yaitu sebesar 0.536 dimana dari semua indikator pada loading factor semua variabel reflektif menunjukkan nilai di atas 0.50 sehingga dapat dikatakan valid dan telah nilai AVE tertinggi berada pada variabel Harga yaitu dengan nilai sebesar 0.722. Variabel tersebut memiliki nilai di atas 0.5 sehingga variabel dapat dinyatakan valid dan dapat dilakukan pengujian olah data selanjutnya.

\section{Uji Reliabilitas}

Uji reliabilitas pada PLS dilakukan pengukuran mempergunakan 2 parameter yakni composite reliability serta Cronbach's alpha dari indikator yang menghitung variabel (Ghozali, 2014, hlm.65). Berikut adalah hasil nilai dari composite reliability yang didapatkan dari output SmartPLS 3.3.2.

Dari Tabel 7, nilai Composite Realibility dan nilai Cronbach Alpha dari semua variabel memiliki nilai > 0,7. Hal ini membuktikan bahwa setiap instrumen pertanyaan pada setiap variabel relevan dan reliabel sehingga dapat dilakukan pengujian olah data selanjutnya.

\section{Uji Koefisien Determinasi}

Koefisien determinasi (R-Square) pada riset ini berfungsi guna pengukuran sejauh memenuhi persyaratan uji validitas konvergen dan kuesioner penelitian ini dengan tepat mengukur variabel dalam penelitian ini.

\section{Uji Validitas Diskriminan}

Berdasarkan Tabel 6, Average Variance Extracted semua variabel bernilai > 0,5 dimana nilai AVE terendah berada pada variabel Keputusan pembelian dengan nilai 0.616 dan mana kesanggupan model ketika menjelaskan variasi variabel tergantung. $\mathrm{R}^{2}$ merupakan indikator yang menggambarkan seberapa banyak variasi yang ada di dalam model.

Berdasarkan Tabel 8, sumbangan variabel bebas yaitu variabel harga, kualitas produk dan promosi terhadap variabel terikat (dependen) yaitu variabel keputusan pembelian sebesar 0,874 atau $87,4 \%$, sedangkan sisanya $13,6 \%$ dipengaruhi oleh variabel di luar model penelitian.

\section{Uji Hipotesis}

Uji hipotesis yang dilaksanakan mempergunakan uji-t yang mana akan memperlihatkan sejauh mana variabel bebas secara satu per satu akan terpengaruh ketika menjelaskan variasi dependen.

Dalam penelitian ini digunakan tabel dua sisi yang telah diketahui nilai t tabel 1,994 yang diperoleh dari nilai persamaan $\mathrm{df}=\mathrm{N}-\mathrm{k}$ atau $\mathrm{df}=75-4=71$ dengan derajat kepercayaan atau signifikasi sebesar $\alpha=0.05$ atau tingkat kebenaran $95 \%$.

Tabel 6. Average Variance Extracted (AVE)

\begin{tabular}{lccc}
\hline Variabel & \multicolumn{1}{l}{ AVE } & Rule of Thumb & Hasil \\
\hline Harga & 0.722 & $>0.50$ & Valid \\
Keputusan Pembelian & 0.616 & $>0.50$ & Valid \\
Kualitas Produk & 0.656 & $>0.50$ & Valid \\
Promosi & 0.619 & $>0.50$ & Valid \\
\hline
\end{tabular}

Tabel 7. Uji Reabilitas

\begin{tabular}{lcc}
\hline \multicolumn{1}{c}{ Variabel } & $\begin{array}{c}\text { Composite } \\
\text { Reliability }\end{array}$ & $\begin{array}{c}\text { Cronbach's } \\
\text { Alpha }\end{array}$ \\
\hline Harga & 0.940 & 0.923 \\
Keputusan Pembelian & 0.950 & 0.942 \\
Kualitas Produk & 0.950 & 0.941 \\
Promosi & 0.941 & 0.930 \\
\hline
\end{tabular}


Tabel 8. R-Square

\begin{tabular}{ccc}
\hline Variabel & R Square & $\begin{array}{c}\text { R Square } \\
\text { Adjusted }\end{array}$ \\
\hline Keputusan Pembelian & 0.874 & 0.869 \\
\hline
\end{tabular}

Tabel 9. Uji T

\begin{tabular}{lllll}
\hline & $\begin{array}{l}\text { Original } \\
\text { Sample } \\
(\mathrm{O})\end{array}$ & $\begin{array}{l}\mathrm{T} \text { Statistics } \\
(|\mathrm{O} / \mathrm{STDEV}|)\end{array}$ & $\begin{array}{l}\mathrm{P} \\
\text { Values }\end{array}$ \\
\hline Harga $\rightarrow$ Keputusan Pembelian & 0.174 & 3.363 & 0.001 \\
\hline $\begin{array}{l}\text { Kualitas Produk } \rightarrow \text { Keputusan } \\
\text { Pembelian }\end{array}$ & 0.156 & 2.404 & 0.017 \\
\hline Promosi -> Keputusan Pembelian & 0.781 & 15.483 & 0.000 \\
\hline
\end{tabular}

Berdasarkan hasil uji $\mathrm{t}$ di atas dapat dilihat bahwa hasil pengujian pada variabel Harga terhadap keputusan pembelian memiliki hubungan yang positif. Hal ini dapat dilihat dari nilai korelasi atau nilai original sampel sebesar 0.174. Jika dilihat dari hasil uji statistik t, hasil data menunjukan $t_{\text {hitung }} 3.363>t_{\text {tabel }} 1.994$ dan dapat disimpulkan bahwa variabel harga berpengaruh terhadap keputusan pembelian. Hal ini dibuktikan dengan nilai $P$-Values atau nilai signifikan sebesar $0.001<0.05$ yang menunjukkan bahwa variabel harga memiliki pengaruh dan signifikan terhadap keputusan pembelian maka H1 Diterima.

Pada Tabel 9, juga dapat dilihat bahwa hasil pengujian pada variabel Kualitas Produk terhadap keputusan pembelian memiliki hubungan yang positif, hal ini dapat dilihat dari nilai korelasi atau nilai original sampel sebesar 0.156. Jika dilihat dari hasil uji statistik t, hasil data menunjukan $\mathrm{t}_{\text {hitung }} 2.404>\mathrm{t}_{\text {tabel }} 1.994$ dan dapat disimpulkan bahwa variabel Kualitas Produk berpengaruh terhadap keputusan pembelian. Hal ini dibuktikan dengan nilai $P$ Values atau nilai signifikan sebesar $0.017<0.05$ yang menunjukan bahwa variabel Kualitas Produk memiliki pengaruh dan signifikan terhadap keputusan pembelian, maka $\mathrm{H} 2$ Diterima.

Berdasarkan Tabel 9, dapat dilihat bahwa hasil pengujian pada variabel Promosi terhadap keputusan pembelian memiliki hubungan yang positif, hal ini dapat dilihat dari nilai korelasi atau nilai original sample sebesar 0.781. Jika dilihat dari hasil uji statistik $\mathrm{t}$, hasil data menunjukan $t_{\text {hitung }} 14.649>\mathrm{t}_{\text {tabel }} 1.994$ dan dapat disimpulkan bahwa variabel Promosi berpengaruh terhadap keputusan pembelian. Hal ini juga dibuktikan dengan nilai $P$ Values atau nilai signifikan sebesar $0.000<0.05$ yang menunjukan bahwa variabel Promosi memiliki pengaruh dan signifikan terhadap keputusan pembelian, maka H3 Diterima.

\section{PEMBAHASAN}

\section{Pengaruh Harga terhadap Keputusan Pembelian}

Berdasarkan pengujian hipotesis yang telah peneliti lakukan menunjukkan bahwa variabel harga memiliki pengaruh dalam meningkatkan keputusan pembelian. Hal ini ditunjukan berdasarakan nilai $\mathrm{P}$ values sebesar $0.001<0.05$ yang menunjukan bahwa variabel harga berpengaruh dan signifikan terhadap keputusan pembelian.

Artinya bahwa indikator-indikator yang ada dalam variabel harga yakni harga sesuai manfaat, harga sesuai kualitas, dan keterjangkauan harga memberikan kontribusi yang besar dalam mempengaruhi keputusan pembelian. Pentingnya penetapan harga pada marketplace Shopee menjadi bahan pertimbangan untuk konsumen dalam melakukan pembelian dan mencegah adaanya pesaing bisnis. Konsumen yang melakukan pembelian di Shopee akan melakukan keputusan pembelian apabila konsumen terseebut merasakan manfaat produk itu lebih 
besar atau sama dengan besar uang yang dikeluarkan, dan juga dengan keterjangkauan harga konsumen dapat membeli produk yang ditawarkan di Shopee dan juga konsumen merasa bahwa bila harga yang ditawarkan lebih tinggi antara 2 pilihan produk maka konsumen akan memilih harga yang lebih tinggi tersebut karena biasanya banyak orang menanggap bahwa kualitas produk sesuai dengan harganya.

Berdasarkan teori Kotler \& Armstrong (2018, hlm.308), harga ialah pengeluaran sejumlah uang pelanggan guna mendapat pemakaian atau manfaat atau kepemilikan dari suatu barang atau pelayanan dimana dapat dilihat bahwa konsumen yang melakukan keputusan pembelian melalui Shopee melakukan beberapa pertimbangan sebelum melakukan pembelian.

Hasil penelitian ini sejalan dengan penelitian yang telah dilakukan sebelumnya oleh Prilano \& Sudarso (2020); Tulangow, Tumbel, \& Walangitan (2019); Ilmiyah \& Indra (2020); Kuswanto \& Vikaliana (2020); Silaban \& Rosdiana (2020); Aryani (2016); Wulandari, Mulyati, \& Tjahjono (2020); Albari \& Safitri (2018); Akbar (2020); Mulya Firdausy \& Idawati (2017) dimana dari hasil riset memperlihatkan bahwa variabel harga memiliki pengaruh terhadap keputusan pembelian.

\section{Pengaruh Kualitas Produk terhadap Keputusan Pembelian}

Berdasarkan pengujian hipotesis yang telah peneliti lakukan menunjukan bahwa variabel kualitas produk memiliki pengaruh dalam meningkatkan keputusan pembelian. Hal ini ditunjukan berdasarakan nilai $P$-values sebesar $0.017<0.05$ yang menunjukan bahwa variabel kualitas produk berpengaruh dan signifikan terhadap keputusan pembelian.

Artinya bahwa semua indikator yang ada dalam variabel kualitas produk yakni penyesuaian, kesesuaian kualitas, keandalan, kemudahan perbaikan, desain memberikan pengarruh dalam keputusan pembelian. Kualitas produk sangat penting dalam mempertahankan sebuah bisnis. Konsumen menyukai berbelanja di Shopee dikarenakan kualitas produk yang diterima tidak mengecewakan dan terdapat banyak variasi desain dari produk. Dari indikator yang dipakai dapat disimpulkan bahwa konsumen menyukai desain produk yang ditawarkan Shopee, kemudian konsumen menyukai berbelanja dishopee karena produknya bisa diubah sesuai permintaan konsumen.

Definisi kualitas produk sesuai pemaparan Kotler \& Keller (2016, hlm.156) yaitu seluruh karakteristik kemampuan akan sebuah barang atau pelayanan sebagai pemenuhan keperluan pemakai dengan implikasi dan ekspresinya merupakan pemberian atas kepuasan konsumen.

Hal ini berkaitan dengan kualitas produk yang ditawarkan Shopee dimana konsumen memilih untuk melakukan keputusan pembelian dikarenakan produk yang ditawarkan dapat memenuhi keperluan atau kebutuhan konsumen dan juga dapat membuat konsumen puas untuk melakukan pembelian di Shopee. Hasil penelitian ini selaras dan sejalan dengan penelitian yang telah dilakukan oleh Akbar (2020) dimana dari hasil riset tersebut menunjukan bahwa variabel kualitas produk memiliki pengaruh terhadap keputusan pembelian.

\section{Pengaruh Promosi terhadap Keputusan Pembelian}

Berdasarkan pengujian hipotesis yang telah peneliti lakukan menunjukan bahwa variabel promosi memiliki pengaruh dalam meningkatkan keputusan pembelian. Hal ini ditunjukan berdasarkan nilai $P$ values sebesar $0.000<0.05$ yang menunjukkan bahwa variabel promosi berpengaruh dan signifikan terhadap keputusan pembelian.

Artinya bahwa promosi yang dilakukan Shopee telah berhasil menarik minat konsumen untuk melakukan pembelian. Bisa dilihat dari indikatornya yakni penjualan langsung (direct marketing), hubungan masyarakat (public relations), penjualan perseorangan (personal selling), promosi penjualan (sales promotion), serta periklanan (advertising). Dengan adanya pemberian gratis ongkos kirim menarik minat konsumen dalam memutuskan untuk melakukan pembelian suatu produk.

Berdasarkan teori dari Kotler dan Armstrong (2017, hlm.78) mengemukakan promosi yaitu kegiatan penyaluran manfaat dengan sifat persuasif yang ditujukan pada pelanggan yang akan memutuskan pembelian. 
Hal ini berkaitan dengan metode promosi yang dilakukan Shopee yang bersifat persuasif sehingga menstimulus konsumen untuk melakukan pembelian. Dengan promosi yang tepat Shopee dapat menjangkau konsumen di seluruh Indonesia.

Hasil penelitian ini selaras dengan penelitian yang telah dilakukan oleh Tulangow, Tumbel, \& Walangitan (2019); Prilano \& Sudarso (2020); Silaban \& Rosdiana (2020) dan Firdausy \& Idawati (2017) dimana hasil penelian tersebut menunjukkan bahwa variabel promosi memilik pengaruh positif terhadap keputusan pembelian.

\section{KESIMPULAN}

Berdasarkan hasil analisis dan pembahasan yang telah dijelaskan sebelumnya mengenai pengaruh harga, kualitas produk dan promosi terhadap keputusan pembelian maka diperoleh kesimpulan harga memiliki pengaruh positif terhadap keputusan pembelian, artinya bahwa penetapan harga pada marketplace Shopee menjadi bahan pertimbangan untuk konsumen dalam melakukan pembelian dan mencegah adanya pesaing bisnis. hal ini sesuai dengan hipotesis yang telah dibuat oleh peneliti.

Selain itu, kualitas produk memiliki pengaruh positif terhadap keputusan

\section{DAFTAR REFERENSI}

Akbar, M. F. (2020). The Influence of Product Quality and Price on Purchasing Decisions at Mitraindo South Tangerang Online Shop. Jurnal Ad'ministrare, 6(2), 237. https://doi.org/10.26858/ja.v6i2.13557

Catriana, El. (2020, July 6). E-Commerce Mana yang Paling Banyak Digunakan untuk Belanja Online Saat Puasa? Kompas. Retrieved from https://money.kompas.com/read/2020/0 7/06/081700426/e-commerce-manayang-paling-banyak-digunakan-untukbelanja-online-saat-puasa?page=all\#: :text=\%22Mengapa Shopee menjadi pilihan utama,pada setiap momen $\% 2 \mathrm{C} \% 22$ katanya.

Chaffey, D., \& Smith, P. (2017). Digital Marketing Excellence: Planning, pembelian, artinya bahwa konsumen menyukai berbelanja di Shopee dikarenakan kualitas produk yang diterima tidak mengecewakan. Hal ini sesuai dengan hipotesis yang telah dibuat oleh peneliti.

Hasil penelitian juga menunjukan promosi memiliki pengaruh positif terhadap keputusan pembelian, artinya promosi yang telah dilakukan Shopee telah menarik konsumen untuk memutukan melakukan pembelian produk. Hal ini sesuai dengan hipotesis yang telah dibuat oleh peneliti.

Adapun saran yang dapat peneliti sampaikan adalah, pertama Shopee harus tetap mempertahankan dan meningkatkan kualitas dari produk-produk yang dijual agar konsumen tertarik untuk terus melakukan pembelian ulang mengingat adanya marketplace lain sebagai pesaing. Shopee diharapkan dapat terus mempertahankan harga dari produk yang dijualnya sehingga dapat terus dijangkau oleh konsumen dan harus terus-menerus menyesuaikan harga produk dengan harga produk marketplace pesaing agar konsumen tidak beralih ke marketplace lain. Kedua Promosi yang dilakukan Shopee juga harus dipertahankan agar konsumen tidak beralih ke marketplace lain. Dan memperluas promosi ke berbagai platform agar semua kalangan menyadari keberadaan marketplace Shopee dan menggunakan aplikasinya.

Optimizing and Integrating Online
Marketing 5th Edition (5th ed.).
Routledge.

Fahrevi, S. R., \& Satrio, B. (2018). Pengaruh Harga, Promosi, dan Kualitas Pelayanan terhadap Keputusan Pembelian Online di Shopee.co.id. Jurnal Ilmu Dan Riset Manajemen, 7(3), 1-15.

Ferdinand, A. (2014). METODE PENELITIAN MANAJEMEN (5th ed.). Badan Penerbit Universitas Diponogoro.

Ghozali, I. (2014). Structural Equation Modeling, Metode Alternatif dengan Partial Least Square (PLS) (4th ed.). Universitas Diponogoro.

Kotler, P., \& Armstrong, G. (2018). Principles of Marketing (17th ed.). United Kingdom: Pearson Education Limited.

Kotler, P., \& Keller, K. (2016). Marketing Management Global Edition (15th ed.). England: Pearson Education Limited. 
Maulana, R. (2021, January 4). Peningkatan Penggunaan E-Commerce disaat Pandemi CoVid-19. Kompasiana. Retrieved from https://www.kompasiana.com/rizkymaul anaalfariz/5ff1fcb18ede483f8763f115/p eningkatan-penggunaan-e-commercedisaat-pandemi-covid-19

Nguyen, X. P. (2019). The Bus Transportation Issue and People Satisfaction with Public Transport In Ho Chi Minh City. Journal of Mechanical Engineering Research \& Developments (JMERD) DOI, 42(1), 1016.

https://doi.org/10.26480/jmerd.01.2019. 10.16

Noor, J. (2014). Analisis Data Penelitian Ekonomi dan Manajemen. Jakarta: PT. Grasindo.

Ovidani, Z., \& Hidajat, W. (2020). Pengaruh Kualitas Pelayanan, Harga Dan Kepercayaan terhadap Kepuasan Pelanggan pada Hotel Dafam Semarang. Jurnal Ilmu Administrasi Bisnis, 9(2), 167-174.

Pasharibu, Y., Paramita, E. L., \& Febrianto, S. (2018). Price , service quality and trust on online transportation towards customer satisfaction. Jurnal Ekonomi Dan Bisnis, 21(2), 240-264.

Pebrianto, F. (2020). Survei APJII: Produk Fesyen Online Paling Dicari, Shopee Jadi Favorit. Tempo. Retrieved from https://bisnis.tempo.co/amp/1404059/su rvei-apjii-produk-fesyen-online-palingdicari-shopee-jadi-favorit

Prilano, K., \& Sudarso, A. (2020). Pengaruh Harga , Keamanan dan Promosi Terhadap Keputusan Pembelian Toko Online Lazada. 1(1), 1-10.
Rachel, C. (2019, December 10). Strategi Shopee dalam Menarik Perhatian Pelanggan. Suara.Com. Retrieved from https://yoursay.suara.com/news/2019/12 /10/131146/strategi-shopee-dalammenarik-perhatian-pelanggan

Setyowati, D. (2020, September 18). Empat ECommerce Berebut Pasar saat Pandemi, Siapa yang Unggul? Katadata. Retrieved from

https://katadata.co.id/desysetyowati/digi tal/5f6494f8a9bcb/empat-e-commerceberebut-pasar-saat-pandemi-siapa-yangunggul

Silaban, B., \& Rosdiana, D. (2020). Bernard E. Silaban dan Desi Rosdiana: " Pengaruh Kualitas Layanan, Harga dan Promosi terhadap Proses Keputusan Pembelian pada Online Shop Sociolla. Jurnal Manajemen Bisnis, 23(3), 202-224.

Sudirman, A., Efendi, E., \& Harini, S. (2020). Kontribusi harga dan kepercayaan untuk membentuk kepuasan pengguna transportasi berbasis aplikasi. Journal of Business and Banking, 9(2), 323-335.

Tulangow, S. G., Tumbel, T. M., \& Walangitan, O. F. C. (2019). Pengaruh Promosi dan Harga Terhadap Keputusan Pada Pembelian PT. Shopee International Indonesia Di Kota Manado. Jurnal Administrasi Bisnis, 9(3), 35. https://doi.org/10.35797/jab.9.3.2019.25 $129.35-43$

Uli. (2020, October 21). Transaksi e-Commerce Naik Nyaris Dua Kali Lipat saat Pandemi. Cnn Indonesia. Retrieved from https://www.cnnindonesia.com/ekonomi /20201021193353-92-561232/transaksie-commerce-naik-nyaris-dua-kali-lipatsaat-pandemi

\section{Copyrights}

Copyright for this article is retained by the author(s), with first publication rights granted to the journal.

This is an open-access article distributed under the terms and conditions of the Creative Commons Attribution license (http://creativecommons.org/licenses/by/4.0/). 